\title{
DIFFERENTIAL OBJECT MARKING AND INFORMATION STRUCTURE: ON THE FUNCTION OF TWO DIFFERENT PRONOMINAL ACCUSATIVES IN KOMI AND KHANTY DIALECTS
}

\author{
Gerson Klumpp \\ University of Tartu
}

\begin{abstract}
The present contribution calls attention to a marginal but interesting phenomenon of variation in grammar, namely the employment of two different accusative markings for pronominal objects encountered (i) in dialect texts from the Komi varieties of Upper Vym' and Luza, and (ii) in varieties of Kazym-Khanty, i.e. in two different branches of Uralic (Permic and Ugric). Based on contextual observations an explanation in terms of information structure is achieved: as will be argued, in both language varieties, additional accusative forms of pronominal object expressions signal their focality resp. non-focality. The study contributes to the theory of differential object marking by establishing focality as one of its parameters.
\end{abstract}

Keywords: differential object marking, information structure, dialectology, personal and demonstrative pronouns, Permic, Ugric

\section{Introduction: differential marking of pronominal object expressions in Uralic}

1.1. In linguistic literature on differential object marking it is generally assumed that pronominal object expressions, especially those referring to speech act participants, are highly probable in being object marked because they are very prominent object expressions (Bossong 1998, Lazard 2001, Aissen 2003, and others). Their prominency is due to their upmost position on the scales of animacy and/or definiteness as in (1a, b). The correlation of prominency of an object expression and its probability of being object marked is understood as due to the fact that animacy and definiteness are considered prototypical subject 
properties. According to the so called markedness reversal an object expression which has these properties must be formally distinguished from the subject by an object marker in order to avoid misinterpretations.

(1) Prominency scales (e.g. Aissen 2003: 437, 442)

a. Animacy scale:

HUMAN $>$ ANIMATE $>$ INANIMATE

b. Definiteness scale

PERSONAL PRONOUN $>$ PROPER NAME $>$ DEFINITE NP $>$ INDEFINITE SPECIFIC NP $>$ NON-SPECIFIC NP

Among pronominal objects 1 st and $2 \mathrm{~d}$ person pronouns are most likely to be object marked because they refer to human speech act participants. With $3 \mathrm{~d}$ person pronouns there is often a distinction between animate and inanimate pronouns, e.g., he, she vs. it, Finnish hän vs. se, Kazym Khanty $\lambda \breve{u} w$ '(s)he' vs. tăm 'this; it'. Again, according to the prominency scales, with animate $3 \mathrm{~d}$ person pronouns object marking is more probable than with inanimate ones, and it is also more probable for personal pronouns than it is for demonstratives. The prominency parameter can be successfully applied to account for several differential object marking patterns concerning pronominal object expressions in Uralic languages. ${ }^{1}$ E.g., in Khanty, object marking occurs exclusively with personal pronouns ${ }^{2}$ as illustrated in (2).

(2) Northern Khanty (Nikolaeva et al. 1993: 132)

$$
\begin{array}{ll}
\text { Ma Petra- } \varnothing \sim l \breve{u} w-e l(* l \breve{u} w) & \text { reska-s-em } \\
\text { I Peter } \quad \text { (s)he-ACC ([s]he.NOM) } & \text { hit-PST-SBJlsG.OBJSG } \\
\text { 'I hit Peter him.' } &
\end{array}
$$

In other Uralic languages object marking is not restricted to personal pronouns but applies to all nouns. Object marking might be generalized (i.e., non differential) as in Hungarian and Mari, or it may work according to the prominency parameter:

1 For general overviews on object marking in Uralic cf. Wickman 1955, Comrie 1975, Alvre 1987, or Bossong 1998.

2 Khanty personal pronouns refer only to persons (men, women, children, ancestors, spirits, etc.); non-persons are referred to by demonstratives (e.g. Kazym tăm 'this'), which - like nouns - have no accusative (Koškareva 2001a: 235). 
only definite objects are in the accusative case, indefinite objects are not. Since personal and demonstrative pronouns are inherently definite expressions they are obligatorily object marked, cf., e.g., the data from Kamas (Samoyed branch) in (3).

(3) Kamas (Joki 1944: 88-90)

a. baltu $i$-bi

axe.NOM take-PST

'she took an axe'

b. $i-b i \quad d \check{l} \quad \check{s}$ amnayə-m

take-PST DEM spoon-ACC

'she took the spoon'

c. măn-a (*măn) i-t

helā-zit-to

I-OBL (I.NOM) take-SBJ2SG.OBJ make.companion-INF-LAT 'take me as a companion!'

d. $i-\check{s}-p e^{\prime} \quad d \check{l}-m(* d \check{l})$

take-IMP-1PL (s)he-ACC ([s]he.NOM)

'let's seize him!'

The following data from Komi-Zyrian (Permic branch) in (4) illustrates the animacy parameter: where a definite inanimate object expression like the city name Syktyvkar in (4a) may be unmarked, animate object expressions like the proper name referring to a dog in (4b) or the 2 nd person pronoun in (4c) must be object marked.

(4) Komi-Zyrian (elicited data)

a. Me l'ubit-a Syktyvkar-ös Syktyvkar.

I like-PRs1sG Syktyvkar-ACC $\sim$ Syktyvkar.NOM 'I like Syktyvkar.'

b. Me l'ubit-a Bobyk-ös (*Bobyk).

I like-PRs1sg Bobyk-ACC (Bobyk.NOM)

'I like Bobyk.'

c. Me l'ubit-a tenö $\left({ }^{*} t e\right)$

I like-PRs1sG you.ACC (you.NOM)

'I like you.'

Non-marking of a direct object may also be due to a specific syntactic context. In Finnish a direct object is in the nominative instead of the genitive-accusative if the verbal predicate of the sentence is an imperative, an impersonal passive, or an 
infinitive form. In this context, again, the nominative object occurs only with nominal object expressions, whereas personal pronouns are obligatorily in the accusative; cf. (5).

(5) Finnish

Vieras $\sim$ hän-et $\left({ }^{*} h a ̈ n\right) \quad$ tuot-iin huonee-seen. guest.NOM (s)he-ACC ([s]he.NOM) bring-PASS room-ILL

'The guest $\sim(\mathrm{s})$ he was led into the room.'

All Uralic patterns mentioned so far are in full accordance with the prediction made by the prominency parameter: in a language, which marks objects differentially, personal pronouns constitute a class of object expressions which is obligatorily object marked. Still, not all patterns of differential object marking are explainable in terms of the prominency parameter as is shown by the following paragraphs on aspect and information structure. Moreover, there is one Uralic language in which, contrary to the above stated obligatoriness of pronominal object marking, only nouns are object marked but personal pronouns are not. In Nganasan only nouns have a distinct accusative-genitive case form, as e.g. in (6), whereas a pronoun as e.g. tonə 'you (sing.)' has the same form when subject as in (7a), or direct object as in (7b). The Nganasan data thus shows that the correlation of high prominency and obligatory object marking reflects a tendency rather then a universal law.

(6) Nganasan (Wagner-Nagy 2002: 79)

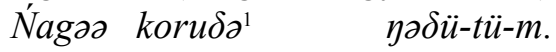
good house.GEN/ACC see-PRS-1sG 'I see a good house.'

(7) Nganasan (Tereščenko 1979: 163)

a. Tana amny ńily-ty- $\eta$. you here live-PRs-2sG 'You live here.'

b. Tənə ńägə" čeny-nty-m. you well know-PRs-1sG 'I know you well.'

3 The nominative form is koru" 'house'. 
1.2. A different object marking parameter is aspect. Among Uralic languages the most prominent example is the partitive object of Finnic languages. Traditionally, the meaning of partitive is twofold: (i) it quantifies nominal expressions as partial (in opposition to total nominative subjects and total genitive objects); (ii) it quantifies predicates as imperfective/irresultative (cf. Denison 1957, Kont 1963, Larsson 1983, Kiparsky 1998, Tveite 2004: 17-20, Huumo 2010). Both partitive meanings, partiality and imperfectivity, have been united under the meaning of unboundedness. Following Kiparsky's (1998) analysis for Finnish a partitive object is part of an unbounded situation whereas a genitive/accusative object is part of a bounded situation. A Finnish pronominal object is illustrated in (8). In a bounded situation, with no restrictions concerning affectedness, as in (8a), the object is in the accusative case. In unbounded situations the object is in the partitive case. Unboundedness can either result from partial affectedness as in (8b), or it is a general property of negated sentences as in (8c).

(8) Finnish (cf. Kiparsky 1998: 280)

a. Näe-n sinu-t. see-1sg you-ACC 'I see you.'

b. Näe-n sinu-a. see-1SG you-PTV 'I'm seeing you, I see a bit of you.'

c. $E-n$ näe sinu-a. not-1sG see.CN you-PTV 'I don't see you.'

In discussing problems of the markedness reversal Næss (2004) unifies the notions of prominency and partial affectedness into a unified DOM parameter which she calls degree of affectedness. The Finnish partitive has often been connected with the prominency notion of indefiniteness, and the accusative with definiteness (e.g. Larsson 1983, Pusztay 1975: 360, Krámský 1972: 194). Still, examples like (8b, c), in which a definite object expression is marked with partitive case despite its high grade of prominency, show that aspect and prominency work essentially 
independently. In addition, there is a difference between the two object marking parameters concerning the number of cases involved: with prominency the opposition is one between an overt case and zero. With aspect (or boundedness) it is one between two overt case markers (cf. Aissen 2003: 436, fn. 3). ${ }^{4}$

1.3 Neither prominency nor aspect can be responsible for the following patterns of pronominal differential object marking found in dialects of Komi (Permic) and Khanty (Ugric). Generally, in these languages object marking with personal pronouns is obligatory (see 1.1 above). In addition, as dialectal phenomena, we find two different pronominal accusative forms, a primary common form $\left(\mathrm{ACC}_{1}\right)$ and a secondary dialect-specific form $\left(\mathrm{ACC}_{2}\right)$. For instance, the Komi 1st person pronoun me ' $\mathrm{I}$ ' has the accusative form menö ( $\left.\mathrm{ACC}_{1}\right)$, as in (9a) and (10a), in all dialects, but in Upper Vym' and in Luza this form alternates with a longer accusative form ( $\left.\mathrm{ACC}_{2}\right)$ menöly in Vym', as in (9b), and menölö in Luza, as in (10b). Similarly, in Kazym-Khanty ma 'I' has a shorter accusative form mănăt, as in (11a), and a longer form, mănătť̆, as in (11b).

(9) Komi-Zyrian, Vym' (Lug; Rédei 1978: 14)

a. Ivan, menö vaj-an, o-n?

Ivan I.ACC 1 bring-PRs2SG not.PRS-2SG

'Ivan, will you marry me, or not?'

b. Vot jeśli-kö te vaj-an menöly, te

so if-COND you bring-PRs2SG I.ACC 2 you

asy lok [...] tat's'sö!

tomorrow come.IMP2sG here.ILL

'So if you then marry me [...] come here tomorrow!'

(10) Komi-Zyrian, Luza (Nošul'; Lytkin 1931: 77)

a. Möj vylö menö jöz-as mytt'ś-önö?

what for me.ACC 1 people-ILL3SG hand.over-PRs3PL

'Why do they hand me over to the people?

4 The distinction between bounded and unbounded is also made for existential subjects, e.g. unbounded Sinua ei ole täällä enää 'You ain't here anymore' vs. bounded Sinä et ole täällä 'You are not here' (cf. also Kiparsky 1998: 294). 
b. Myt's’s-önö menölö bur jöz ord-ö. hand.over-PRS3PL me.ACC 2 good people at-ILL 'They do hand me over to good people.'

(11) Kazym Khanty (Koškareva and Solovar 2004: 279-280)

a. Mănăt nux kürit-e ‥ śos-n! me.ACC 1 up wake-IMP.SBJ2SG.OBJSG clock-LOC 'Wake me up at ... o'clock!'

b. Mănătť̆ nux kŭrit-e! me. ACC $_{2}$ up wake-IMP.SBJ2SG.OBJSG 'Wake me up!'

The parallel use of two different pronominal accusative case forms as in (9)-(11) has received comparably little attention in the literature. The works that do exist do not sufficiently explain their different functions (cf. for Vym' Žilina 1998: 57-58, 94-108, Ljašev 1975: 92-93, Ljašev 1977, Baker 1985: 202-221, for Luza Žilina 1985: 62-63, and for Kazym Koškareva 2001a, $2001 b, 2002)$. What seems clear is that the prominency parameter cannot be applied to account for variations of the type menö menöly in (9), or mănăt mănătť 'me' in (11): different forms of the 1st person pronoun do not differ in degrees of animacy or definiteness. And, as the examples cited show, the different object forms are not due to different verb semantics. Less obvious may be irrelevance of aspect, or degree of affectedness. It could be possible that different aspectual readings are achieved by changing the form of the object. Such a pattern, on the other hand, is not known neither in Komi nor in Khanty. Perhaps with the exception of the question in (10a), there is also no reason to look for different degrees of affectedness. Therefore, another parameter has to be identified. Such a parameter may be found in the domain of information structure. Lazard (2001: 878-879) explicitly lists thematicity ( $\sim$ topicality) of the object as a relevant factor for object marking in Persian, Romance, and other languages, and also object rhematicity ( focality) in Badaga, Arabic and others. ${ }^{5}$ In Northern Khanty, as Nikolaeva $(1999,2001)$ has demonstrated,

5 For the tradition of the different terms theme or topic or old information vs. rheme or focus or new information cf., e.g., Molnár 1991: 12-35. 
object agreement is triggered exclusively by the secondary topic status of the object. And finally, Baker (1985: 212-215) assumed that topicality may be a relevant factor for Vym' and Luza object marking patterns as in (9b) and (10b).

In the following section 2. it is specified what kind of impact information structural notions may have on object marking. As we argue, the form of the object may depend on enclosure resp. non-enclosure into the focus of an uttering. In sections 3 . and 4. the variation exemplified in (9)-(11) is treated in detail and explained in terms of focality. Conclusions are presented in section 5. The data comes from Komi and Khanty text publications as well as from unpublished archive material collected at the Komi Research Centre in Syktyvkar in 2007. The main purpose of the paper is to offer an explanation for a puzzling grammatical variation encountered in dialect texts. The discussion has to based on these data.

\section{Information structure as a parameter of differen- tial object marking}

The basic assumption which underlies the following explanations is that the surface form of a direct object expression may depend on its enclosure (or non-enclosure) into that part of an uttering which constitutes the focus of this uttering. Focus means new information as opposed to given (old, presupposed, topical) information (cf. Schwarzschild 1999, Krifka 2007). E.g., a sentence of the type The doctor helped him quickly can have different readings, depending on the type of given or new information provided. By focus accent - indicated here by capital letters - a speaker highlights this part of the sentence which is to be understood as the new information. A neutral reading of this sentence would be The doctor HELPed him imMEDiately, asserting the immediate act of helping against a presupposed background \{He needed help, there was a doctor\}. A reading The doctor helped him immEDiately, with focus only on the adverb, presupposes the act of helping. Focus on the object pronoun as in 
The doctor helped HIM immediately yields a contrastive reading which could also be expressed with a different syntactic construction: It was him, who the doctor helped immediately. The crucial point is that in languages other than English an equivalent to focal HIM might be expressed differently from a non focal (given) him. This difference may not only be due to narrow focus on HIM but also to a general differentiation between being part of the focus or not. The focus of a sentence can consist of more than one expression but only one can have focus accent. In this case it is appropriate to distinguish the focus independently from the focus accent using brackets, e.g., The doctor $[\text { HELPed }]_{\mathrm{FOC}}$ him vs. The doctor [HELPed him $]_{\mathrm{FOC}}$ where the first sentence is an appropriate answer to a question What did the doctor do to him? with everything presupposed except the predicate. The second sentence is an appropriate answer to the question What did the doctor do? where the object is not a part of the presupposition. In other words, it may be crucial for the form of a direct object whether it is a given expression which is part of the presupposition of a sentence (i.e. a topic expression in the tradition of Lambrecht 1994, and Nikolaeva 1999, 2001), or whether it is a focus expression, which is part of the assertion. Givenness of the object will be identified in section 3. as the responsible factor for the choice of the longer accusative form in Vym' and Luza. And in section 4. we show that in Kazym it is, conversely, focality which triggers the longer accusative form.

\section{Two different accusative forms of personal and demonstrative pronouns in the Komi dialects of Vym' and Luza}

3.1.1. The Komi-Zyrian dialect of Upper Vym' shows within its case system of personal and demonstrative pronouns two accusative forms: 1 st-3d person singular pronouns and the $3 \mathrm{~d}$ person plural pronoun as well as demonstrative pronouns meaning 'this' and 'that' have a standard accusative form and a so called "accusative-dative form" (the form which was glossed 
"ACC ${ }_{2}$ " in the introductory examples (9b) and (10b) above). The name of the latter is due to its morphological structure, which is a combination of the standard pronominal accusative form plus the dative ending -ly. Note that the accusative-dative is distinct from the dative form of the respective pronouns as can be seen in table $1 .^{6}$

Table 1. Syntactic cases of personal and demonstrative pronouns in Upper Vym' (cf. Žilina 1998: 93).

\begin{tabular}{llllll}
\hline & 1st sing. & 2nd sing. & $\begin{array}{l}\text { 3rd sing. } \\
\text { distal } \\
\text { demon- } \\
\text { strative }\end{array}$ & $\begin{array}{l}\text { proximal } \\
\text { demon- } \\
\text { strative }\end{array}$ & 3rd plur. \\
\hline nom. & me & te & sija & tajö & naja \\
acc. & menö & tenö & sijö & tajö & najö \\
acc.-dat. & menöly & tenöly & sijöly & tajöly & najöly \\
dat. & men $(y m)$ & ten $(y d)$ & syly & taly & naly \\
\hline
\end{tabular}

3.1.2. As stated above, the difference in meaning between accusative and accusative-dative as e.g. in sijö sijöly cannot be expressed in terms of prominency (definiteness, animacy) nor in affectedness of the object nor in terms of aspect of the situation. In trying to explain the function of the morpheme -ly with direct objects Frolova (1950: 137), Ljašev (1975: 94) and others (e.g. Serebrennikov 1963: 44) identified it as emphasis ("èmfatičeskoe vydelenie"), and labelled the morpheme -ly an "emphatic particle" (dative semantics thereby considered completely irrelevant). An interpretation of menöly 'me' in (9b) - repeated here as (12b) - as an emphatic object form, opposed to neutral menö in (12a), would achieve a contrastive reading: "Now, that you marry ME (and not anybody else)". In other words, the longer form would signal contrastive focus on the pronominal object.

6 The dative forms of 1st and 2nd person pronouns also show a shorter and longer form: men $\sim$ menym and ten $\sim$ tenyd. This alternation has to remain outside the scope of this paper. 
(12) Komi-Zyrian, Vym' (Lug; Rédei 1978: 14)

a. Ivan, men̈̈ vaj-an, o-n?

Ivan I.ACC bring-PRS2SG not.PRS-2SG

'Ivan, will you marry me, or won't you?'

b. Vot jeśli-kö te vaj-an menö-ly, te

so if-COND you bring-PRS2SG I.ACC-DAT you

asy lok tat't'sö!

tomorrow come.IMP2SG here.ILL

? 'So if you then marry [me $]_{\mathrm{FOC}}$, come here tomorrow!'

For the structural parallel object form sijöly in (13), on the other hand, an interpretation operating with contrastive focus or emphasis on the object pronoun runs into difficulties. These attempts must fail because emphasis here has to be put clearly on other elements. The sentence can only be understood correctly with (i) contrastive topic accents on the subject expressions, and (ii) contrastive focus accents on the predicates: $I_{\text {стор }}$ [will make her $_{\mathrm{x}}$ fall ILL $]_{\mathrm{FOC}}$, and YOU ${ }_{\text {стор }}$ [go about to CURE $]_{\mathrm{FOC}}$ her $_{\mathrm{x}} \mathrm{x}^{7}$ The actual emphasis within the clause where the accusative-dative pronoun occurs, is on the contrastive topic expression te 'you' and on the contrastive focal predicate let'sitny kut'sis' 'go about to cure', but not on the object expression sijöly.

(13) Komi-Zyrian, Vym' (Koni; Frolova 1948/49: 61)

Context: "Death," in order to help a friend in becoming rich, sends him as a doctor to a rich merchant whose daughter is supposed to fall ill.

Sy-lön pö vyjym nyy, Smert-yd šu-ö.

(s)he-GEN QUOT exists daughter Death-2sG say-PRs3sG

Me pö sijö viśöm-ö uśköd-a,

I QUOT (s)he.ACC illness-ILL make.fall-PRs1sG

a te pö sijö-ly let'sit-ny kut'sis'!

and you QUOT (s)he.ACC-DAT cure-INF go.about.IMP2SG

'He has a daughter, says Death. $[\mathrm{I}]_{\text {стор }}$ [will make her fall ill $]_{\mathrm{FOC}}$ and $[\mathrm{you}]_{\text {СтоP }}$ [go about to cure $]_{\mathrm{FOC}}$ her!'

7 The bracketing decision here and in the following is, that a non-focal object constituent simply remains outside the brackets as in "[go about to CURE $]_{\mathrm{FOC}}$ her", but if such a constituent has to appear within the focal sentence part it will appear in brackets marked as topic, as e.g. in (23) "[mash $[i t]_{\mathrm{TOP}}$ upon the stove $]_{\mathrm{FOC}} "$ 
Judging on the base of (13) the meaning of the accusative-dative form is just the opposite of emphasis, namely deaccenting. Now, with the background of (13), let us reconsider our interpretation of (12b) which was 'Now, that you marry ME (and not anybody else)'. The question 'Ivan, will you marry me?' in (12a) introduces the idea of marriage into the discourse. The question is answered in the affirmative and in (13b) the future bride makes preparations on how to proceed: 'So [IF then $]_{\mathrm{FOC}}$ you marry me, come here tomorrow!' In this sentence all constituents (subject, object, verbal predicate) can be understood as given (presupposed) and there is no contrastive emphasis on the pronoun menöly. Instead, there is narrow focus on the the conditional particle jeśli-kö 'if, if then'. The pronoun is not part of the focus, it rather seems to indicate that focus is on a different syntactic element, in this case on the only new element in the sentence, the conditional particle jeśli-kö 'if, if then'. The result so far is that the former reading with contrastive emphasis on the accusative-dative pronoun must be abolished; the final reading for (12b) is expressed in (14).

(14) Komi-Zyrian, Vym' (Lug; Rédei 1978: 14)

Vot jeśli-kö te vaj-an menö-ly,
so if-COND you bring-PRs2sG I.ACC-DAT
te asy lok tat'śöo!

you tomorrow come.IMP2SG here.ILL

'So [if $]_{\mathrm{FOC}}$ you then marry me, come here tomorrow!'

3.1.3. The following example illustrates a different case of narrow focus on a constituent which is not the pronominal object expression. In (15b) this constituent is the subject pronoun. Both questions in (15) are asked by a father who needs to be rescued by one of his daughters. First, (15a) is addressed to his eldest daughter who refuses to help him. After that he asks his second daughter (15b): "Will [YOU ${ }_{\mathrm{FOC}}$ not save me?" Again, the emphasized element is not the accusative-dative pronoun.

(15) Komi-Zyrian, Vym' (Lug; Rédei 1978: 22)
a. $O-n-\ddot{o}[\ldots]$
bat'-sö
vyrut'sit?
not-PRS2sG-Q father-ACC3sg help.CN
'Won't you save Dad?' 
b. $O-n-\ddot{o}$ te menö-ly mynty pe? not-PRS2SG-Q you me.ACC-DAT rescue.CN QUOT 'Will [you $]_{\mathrm{FoC}}$ not save me?'

While in the preceding examples the new information could be associated with constituents - a verbal predicate in (13), a conditional particle in (14b), a subject expression in (15b) - in the following two examples the new information cannot be associated with such a specific constituent; at least not in the Komi text. In the English translations such an assiciation is possible: it is the auxiliary which bears focus accent: DID in (16b) and WILL in (17). Both examples represent so called verum focus, where the new information consists in the confirmation of an already established proposition with all elements given. This type of focus is quite common with repetitions in narratives for which (16b) is an example. In (16a) a proposition is established: a tsar and his wife send a soldier to the tsarevič. The predication in (16b) repeats and confirms this proposition.

(16) Komi-Zyrian, Vym' (Lug; Rédei 1978: 34)

Context: While the tsarevič is out of town, his wife has given birth to a child.

a. [...] seśśs sar gozja-ys $i$ saldat-ös yst-isny then tsar couple-3SG and soldier-ACC send-PST3PL pi-ys din-ö: myj sy-ly ńim-sö boś-ny? son-3sg to-ILL what (s)he-DAT name-ACC3sg take-INF '[...] and then the tsar and the tsarina sent a soldier to their son, saying, "What name shall the boy be given?"”

b. Ystisny sijö-ly, saldat-ös. send-PST3PL (s)he.ACC-DAT soldier-ACC 'They [did] ${ }_{\mathrm{FOC}}$ send him, the soldier.'

Verum focus is also the motivation for the use of an accusative-dative pronoun (17). The text fragment starts with the decision of a poor brother to invite his rich brother to a party. The following sentence provides background information in recalling an earlier reverse situation; the new information in this sentence consists in the reversal of subject and object roles, and in the negation of the given predicate kor- 'invite'. This situation is, again, reversed, repeating thus the first sentence, but 
replacing the object expression by a pronoun. The focus in this sentence consists in the confirmation of the already established proposition, and this focus reading is enabled by the choice of the explicitely non-focal object expression.

(17) Komi-Zyrian, Vym' (Koni; Frolova 1948/49: 57) Göl' vok-ys $i \quad \check{s} u-\ddot{o}, \quad$ "Me pö ozyr poor brother-3sG and say-PRS3SG I QUOT rich vok-ös kor-a žö bal vyl-as. Sija menö brother-ACC1sG invite-PRs1sG AFF party on-ILL3SG (s)he I.ACC $i-z \quad k o r l y, \quad$ a me kor-a sijö-ly." not.PST-3SG invite.CN but I invite-PRs1sG (s)he.ACC-DAT "And the poor brother says: "I shall invite my rich brother to the party. $[\mathrm{He}]_{\text {стор }}[\text { did not invite me }]_{\mathrm{FOC}}$ but $[\mathrm{I}]_{\text {стов }}$ [will $]_{\mathrm{FOC}}$ invite him."

3.1.4. In summary it can be stated, that a pronominal accusative-dative form in Vym' is an object expression signaling that it is not part of the focus of the sentence. This is especially clear with narrow focus contexts as, e.g., subject constituent focus in (15b). Former analyses which interpreted the accusative-dative marked pronoun as an emphatic object expressions, appear to be wrong as our readings of examples (13)-(17) have shown. Moreover, it can be demonstrated that if a pronominal object expression has narrow focus it is in the accusative case and not in the accusative-dative case: in (18) the main protagonist is object of an attempt, he shall be killed by a bunch of rascals. In order to irritate them he starts preparations for a trick: pretending that he does not want to leave a dolorous widow behind he will apparently stab her before he gets killed himself (what he'll really stab is a bladder filled with red water). In explaining this plan to his wife he says me pö pervej tenö vija 'I will first kill you', with contrastive object focus. The act of killing (or pretending to do so) is presupposed by the preceding context, but the object is not. The object is not a contrastive topic, since the expected arguments of the killing event are the main protagonist and the rascals, but not the wife. The object expression thus bears a clear contrastive focus accent. The form is accusative, not accusativedative. 
(18) Komi-Zyrian, Vym' (Koni; Frolova 1948/49: 22)

Context: A trickster protagonist expects a bunch of rascals, who want to kill him, and develops a strategy:

Baba-ys-ly gad'd'- $\ddot{0}$ kraska va pukt-is wife-3SG-DAT bladder-ILL red water put-PST3SG kunul-as. “Žulik-jas kö pö kut'ts'-asny vi-ny, armpit-ILL3SG rascal-PL COND QUOT begin-FUT3PL kill-INF me pö pervej tenö vij-a, o-g kol' I quot first you.ACC kill-PRs1sG not.PRS-1sG leave.CN mut'sit't'sy-ny, purt-ön pö tšuköd-a gad'd'-ad." suffer-INF knife-INS QUOT stab-PRs1sG bladder-ILL2SG 'He puts a bladder with red water under his wife's armpit (and says): "If the rascals come and start to kill, I first kill [you $]_{\mathrm{Foc}}$, I don't leave you (alone) suffering, I stab into this bladder of yours with a knife."

3.1.5. In Komi dialects, a special object marking strategy for presupposed objects involving the dative is not exclusively found with pronominal objects. In Vym', as well as in other dialects of Komi-Zyrian (Ižma, Luza-Letka, Vym') and KomiPermyak (Kosa-Kama, Kočëvo) it applies to nouns as well (see Baker 1985: 202-221, Klumpp 2009). Morphologically the dative marked direct object has the same form as an indirect object, i.e. other than with pronouns, a presuppositional nominal object is marked by dative case proper and not by a special accusativedative case. Its function is basically the same as the function of the accusative-dative marked pronominal objects: it signals givenness (presupposedness, topicality) of the direct object. For illustration cf. (19b) where a dative marked direct object, kerkaly 'the house', occurs in a narrow focus context with focus on the adverbial expression setšöm ńeštšaśliveja 'in such an unlucky way'.

(19) Komi-Zyrian, Vym' (Onež'e; Žilina 1998: 425)

a. zavödit-isny vör kerka kar-ny. undertake-PST3PL forest house make-INF 'they [undertook to build a forest hut $]_{\mathrm{FOC}}$ '.

b. Naja setšöm ńeštšaśliveja kut'ts'isny kerka-ly they so unluckily begin-PST3PL house-DAT 
kar-ny: Kodi ki-sö rańit-ö,

make-INF who hand-ACC3SG hurt-PRs3G

kodi kok-sö.

who foot-ACC3SG

'They began building the hut [in such an unlucky way $]_{\mathrm{Foc}}$ ' one hurts his hand, one his foot.'

In the other dialect of the Northern dative object areal, in Ižma, instances as (20) occur, where a regular dative form of the pronoun is employed as a direct object expression. In (20), from a Kolva epos, nyly (instead of accusative naje) is a continued topic expression, the referent switched from subject role in the preceding sentence to the object role in the present sentence, the new information is constituted by the subject and the predicate. Possibly, there is narrow focus accent on the subject: [a STRONG GALE blew [them $]_{\mathrm{TOP}}$ off course $]_{\mathrm{FOC}}$, and the dative marked pronoun enables this reading.

(20) Komi-Zyrian, Ižma (Kolva; Vászolyi-Vasse 2001: 52)

More šör-e pet-inys da

sea middle-ILL go.out-PST3PL and

ydžyd töö daj kysk-is ny-ly

big wind and pull-PST3sG they-DAT

parus-jas-nysse kośool-is

sail-PL-ACC3PL tear.apart-PST3SG

'They sailed out to the high sea, [a strong gale blew $[\text { them }]_{\mathrm{TOP}}$ off course $]_{\mathrm{FOC}}$ and tore apart the sails'.

Instances of dative marked pronominal object expression have been reported also from Northern Permyak dialects (Batalova 1975: 141).

3.2. Accusative-dative marked pronominal objects as in Vym' are found also in Luza, a Southern dialect of KomiZyrian which is not adjacent to Vym'. To be exact, for the Luza area accusative-dative-forms have been reported from Čitaevo, Ob"jačevo, Nošul' and Lovlja, the latter is situated between the rivers Luza und Letka. In Luza the same pronouns as in Vym', except for the 3rd person plural pronoun nida, show two object forms. As can be seen from table 2, morphologically we face the same accusative form as well as the same combined accusative- 
dative form, the only difference consists in the quality of the suffix vowel.

Table 2. Syntactic cases of personal and demonstrative pronouns in Luza (cf. Žilina 1985: 62-63).

\begin{tabular}{llllll}
\hline & 1st sing. & 2nd sing. & $\begin{array}{l}\text { 3rd sing. } \\
\text { distal } \\
\text { demon- } \\
\text { strative }\end{array}$ & $\begin{array}{l}\text { proximal } \\
\text { demon- } \\
\text { strative }\end{array}$ & 3rd plur. \\
\hline nom. & me & te & sija & tajö & ńida \\
acc. & menö & tenö & sijö & tajö & ńidaös \\
acc.-dat. & menölö & tenölö & sijölö & tajölö & - \\
dat. & me(ny)m $m$ & te $(n y) d$ & si(ja)lö & ta(ja)lö & ńidalö \\
\hline
\end{tabular}

Concerning the function of this category in Luza there is nothing new to be stated. Dialect texts from the above mentioned settlements are scarcer than texts from Upper Vym', examples rather rare. Still, there are instances which call for explanation. A successful interpretation of the Luza pronominal object forms in (10) - repeated as (21) below - can be achieved with the same focus type readings as in Vym'. In (21b) this is a reading with verum focus. (21) is a fragment from a wedding song in which the bride laments over the fact that she will be handed over to her husbands family. In the first mention in (21a) the object is not presupposed in this role and, consequently, the focal accusative form menö 'me' is used. In (21b), after resignating over the fact that she cannot do anything to it, the situation expressed before is repeated, now with an accusative-dative form of the pronoun.

(21) Komi-Zyrian, Luza (Nošul'; Lytkin 1931: 77)

a. Möj vylö men̈̈ jöz-as mytt'ś-önö? what for me.ACC people-ILL3SG hand.over-PRS3PL 'Why do they hand me over to the people?

b. O-g mena vermy nem vöt's-ny-sö. not.PRS-1SG I still can.CN nothing do-INF-ACC3SG Myt't’s-önö menö-lö bur jöz ord-ö. hand.over-PRS3PL me.ACC-DAT good people at-ILL 
'I can't do anything anymore. / They [do $]_{\mathrm{FOC}}$ hand me over to good people.'

A verum focus reading is also possible for (22), which appears as an isolated sentence in N. Loskutova's (1972) field materials from Ob"jačevo; therefore, in the English translation, the focus is constituted by the auxiliary verb. However, if the idea of forgetting is the new information in this sentence, then a reading with narrow verb focus is appropriate, as indicated in the second translation by the focus accent on the main verb. Note that this sentence would allow to observe a correlation between verum focus and VSO word order, i.e. fronting of the verbal predicate; due to subject pro-drop, the above instances of verum focus (16b) and (21b) show the rather unspecific word order VO.

(22) Komi-Zyrian, Luza (Ob”jačevo; Loskutova 1972: 52)

Vunöd-an te menö-lö.

forget-PRS2SG you me.ACC-DAT

(i) Verum focus: You [will $]_{\mathrm{roc}}$ forget me.

(ii) Predicate focus: You [will forget $]_{\mathrm{FOC}}$ me.'

In (23) the object expression sijölö is a clear case of a continued discourse topic with word order OV.

(23) Komi-Zyrian, Luza (Ob”jačevo; Loskutova 1972: 61)

Śu kötöd-amö, t’śužt-amö śs-sö,

rye soak-PRs1PL let.germinate-PRs1PL rye-ACC3SG

seśa sijö-lö jummöd-am patt’öör-yn.

then (s)he.ACC-DAT mash-PRS1PL stove.coverage-INE

'We soak rye, let the rye germinate, then we [mash [it $]_{\text {TO }}$ upon the stove $]_{\mathrm{FOC}}$ '.

Finally, (24) parallels the Vym' example (14) above. The example comes from a tale about a poor boy who gets into grief for having shot a beautiful duck's wing with an arrow. The duck turns out to be a rich and beautiful girl who lives inside the lake and is willing to reward the boy's compassion with her love. Again, we find a conditional particle as the focus element in a surrounding of given elements.

(24) Komi-Zyrian, Luza (Nošul'; Kuznecov 2005: 70)
a. "[...] a öni lo-in
te menam žal, $[$...]"
and now become-PST2SG you I.GEN sorry 
'(The boy says): "[...] but now I feel regret [...]".

b. "Te kö menö-lö žalit-an, me tenyd zev bur you COND I.ACC-DAT pity-PRS2SG I you.DAT very good vöt's-a $[\ldots] "$

make-PRs1sG

'(The girl says): "[If $]_{\mathrm{FoC}}$ you then have compassion for me, ${ }^{8}$ I will do you much good."

3.3. In this section we have demonstrated how the information structural category of focus functions as a parameter of differential object marking. We advocated for the interpretation of the accusative-dative form of pronouns, which is a dialect specific innovation in the Komi-Zyrian dialects of Vym' and Luza, as a special form for non-focal object expressions. This form indicates that the object expression is not part of the focus, often in sentences with narrow focus on a constituent other than the object itself.

\section{Two different accusative forms of personal pronouns in Kazym-Khanty}

4.1. Khanty personal pronouns are inflected in the accusative and dative case. In addition, the inflectional paradigm of personal pronouns in Kazym Khanty shows two variants of these case markers, a morphologically simple case and a more complex one. The simple dative form consists of the stem of a respective pronoun followed by a homodeictic possessive suffix - a pattern found throughout Khanty dialects. In the complex dative form a suffix $-a$ is added, which is the lative case suffix from the nominal declension. Concerning the accusative, the simple form has the common Khanty pronominal accusative suffix $-t$. The complex form adds an $-i$, whose etymological origin is unknown to me. Table 3 shows only the singular forms,

8 The original English translation (ib.) says "After all, you had compassion for me..." which is not an exact equivalent; the Russian translation is closer to the meaning of the Komi text: "Kol' ty menja žaleeš', ya tebe dobro sotvorju". 
but dual and plural personal pronouns are affected in the same way. Note that Kazym is not a homogenous dialect but consist of subvarieties, of which several do not distinguish two different accusative forms, some even do not distinguish accusative and dative in their pronominal inflection (cf. Nëmysova et al. 1996: 15, 21).

Table 3. Case marking of singular personal pronouns in Kazym (cf. Koškareva 2002: 29).

\begin{tabular}{llll}
\hline & 1st sing. & 2nd sing. & 3rd sg. \\
\hline nom. & ma & năy & $\lambda \check{u} w$ \\
acc $_{1}$ & manət & năyət & $\lambda \check{u} w \partial t$ \\
acc $_{2}$ & manti & năgti & $\lambda \check{u} w t i$ \\
dat $_{1}$ & manem & năyen & $\lambda \check{u} w e \lambda$ \\
dat $_{2}$ & manema & năyena & $\lambda \check{u} w e \lambda a$ \\
\hline
\end{tabular}

4.2. There is contradictory information concerning the different uses of these pronominal case forms. Firstly, for the dative forms, Koškareva (2002: 30) explains that the simple form is used in thetic (all new) sentences as in (25a), as well as in topic-focus sentences, where it constitutes a topic expression, cf. (25b). The complex form is used in topic-focus sentences as a focus expression, cf. (25c). Judging from this example the complex form is used with narrow focus on the pronoun.

(25) Kazym Khanty (Koškareva 2002: 41)

a. What happened? (thetic context) ma wŭx-em năy-en mă-s-əm I money-1sG you-DAT ${ }_{1}$ give-PST-1SG '[I gave you my money $]_{\mathrm{FOC}}$,

b. What did I give to you? (topic-focus context with topical pronoun)

ma năy-en $[w \breve{u} x-e m]_{\mathrm{FOC}} m a \breve{a}-s-e m$ I you-DAT ${ }_{1}$ money-1sG give-PST-SBJlsG.OBJSG 'I gave you [my money $]_{\mathrm{Foc}}$,

c. Whom did I give my money to? (topic-focus context with focal pronoun) 


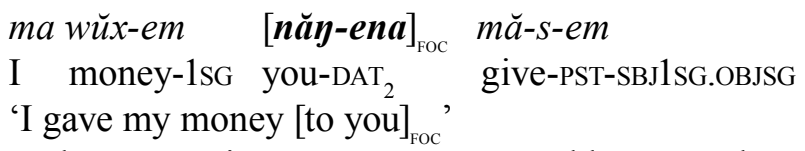

For the accusative pronouns we would expect the same distribution, i.e. the longer form in $-i$ functioning in contexts where there is narrow focus on the pronoun. According to Rédei (1968: 21) complex case forms are emphatic ("nachdrücklich"), an observation which, at least, is not contradictory to the notion of narrow focus. Koškareva (2001: 112) only points out that there is a general difference between thematic ( topical) and rhematic ( $\sim$ focal) pronouns in Kazym, but she provides examples only for the dative case. Moreover, in another article Koškareva (2001: 238) claims that manat $\sim$ manti 'me (ACC)', năyat $\sim$ năgti 'you (ACC)' etc. are "regional variants". However, there is clear counterevidence, because these variants occur with one and the same speaker. In Kazym text publications the variation in question occurs with at least five speakers: N. P. Kaksin from Amninskie uses manat 'me' in OA III: 478, 479 and manti id. in OA III: 391, 443, 479, 482; M. K. Tarlina from Juil'sk uses năyzt 'you' in Rédei 1968: 66 but nănti id. in Rédei 1968: 86, 92; similar variation is found with A. M. Moldanov from Juil'sk in Moldanov 2001: 165, 177 vs. op. cit.: 145, 164, 177; with V. N. Tarlina from Kazym in Moldanov 2001: 180, 182 vs. op. cit.: 180; with N. M. Lozjamov from It'-jaxa in Moldanov 2001: 218 vs. op. cit.: 218. In consequence, a closer inspection of this variation in search for a functional difference seems appropriate.

Let us try to interprete the above example (12) - repeated as (26) below - along the notion of narrow focus or emphacy as given by Koškareva (2002: 30) and Rédei (1968: 21). The simple form in (26a) can be appropriate here either because (i) it is an all-new-context, (ii) the object expression is the only topical constituent, or (iii) the time adverbial has narrow focus; cf. the focus brackets in the English translations. ${ }^{9}$ The correct interpretation of (26b) - according to our information thus far - would be (i), with narrow focus on the object expression. However, in the case

9 The original Russian translation is added in brackets. 
of the time adverbial in (26a) narrow focus seemed quite natural in a conversation guide, whereas in the case of the pronominal object in (26b) it appears somehow very specific. As a solution for (26b) one could think that the longer accusative form does not necessarily trigger a reading with narrow focus, but simply signals that the object expression is part of the focus, as in the translation in (ii). But in the case of (26b) this would mean that the sentence is thetic (all new), a context whereby Koškareva (2002: 30), in case of the dative forms, predicts the use of the shorter form. Obviously, there is a dilemma. The question is: does the complex accusative form only signal narrow focus on the object, or does it signal focality of the object?

(26) Kazym Khanty (after Koškareva and Solovar 2004: 279-280)

a. Mănăt nux kŭrit-e $\quad \ldots \quad$ śos- $n$ me.ACC 1 up wake-IMP.SBJ2SG.OBJSG clock-LOC (i) all-new: '[Wake me up at ... o'clock $]_{\mathrm{Foc}}$ !'

(ii) topical object: '[Wake $[\mathrm{me}]_{\mathrm{TOP}}$ up at ... o'clock $]_{\mathrm{FOC}}$ !' (iii) narrow focus: 'Wake me up [at ... o'clock $]_{\mathrm{FOC}}$ !' ('Menja razbudi v ... časov!')

b. Mănătť̆ nux kŭrit-e me. $\mathrm{ACC}_{2}$ up wake-IMP.SBJ2sG.OBJSG

? (i) narrow object focus: 'Wake $[\mathrm{me}]_{\mathrm{Foc}}$ up!'

? (ii) all-new:

('Razbudi menja!') '[Wake me up $]_{\mathrm{FOC}}$ !'

The interpretations concerning focality of the pronouns in the isolated sentences in (25) are somehow of a purely speculative nature. The following examples from narratives allow for a discussion on a contextual basis.

The difference in meaning between the supposed topical form mant 'me ( $\left.\mathrm{ACC}_{1}\right)$ ' in (27a) and the supposed focal variant manti 'me $\left(\mathrm{ACC}_{2}\right)$ in $(27 \mathrm{~b})$ can be understood as a difference in alternatives. While in (27a) there is no alternative object referent to take over, in (27b) there is one, because (27b) is uttered by a second hero, who had appeared after the first hero and who is about to kill the first one and then return in his place. The alternative consists in this first hero, and the object can be con- 
trastively emphasized: 'wait for ME (and not the other one)'. Thus (27b) supports the idea of narrow object focus.

(27) Kazym Khanty (Amninskie; OA III: 478-479)

a. Context: The protagonist is in a boat on a river, suddenly there appears an armoured hero, steps down to the river and addresses the protagonist:

wŭņšpt-e mant pa peḷk-a såra! take.over-IMP.SBJ2SG.OBJSG I.ACC 1 other side-LAT quickly ' $\left[\text { take }[\mathrm{me}]_{\mathrm{TOP}} \text { quickly over to the other side }\right]_{\mathrm{FOC}}$ !'

b. Context: After having taken him over a second hero wants the same. Again, the main protagonist does as requested. This second hero, finally, jumps ashore and says:

\section{manti $\lambda a w \lambda-e \quad t a ̆ t a !$}

I.ACC $_{2}$ wait.IMP.SBJ2SG.OBJSG here

'wait here for $[\mathrm{me}]_{\mathrm{FOC}}$ !'

In interpreting the next example (28a) we read the simple accusative form mănət 'me' as non-focal in the context of narrow predicate focus. This is a plausible reading because the situation in which the request to kick is uttered, involves clearly both protagonists, the addressee and the speaker, who arrived at the place together and are now bound to separate. The question underlying the request is "What are you supposed to do now in respect to me?". This request is first followed by a predication about what will happen to the horse, and then, in (28b), advice concerning the future of the addressee. If he should happen to get into trouble, he is supposed to do the following: look for his horse. The underlying question, not presupposing the occurence of the object referent, is now "What are you supposed to do?". Obviously with this question, it is not necessary to read the longer form in (28b) as a contrastive one: "look for ME (and for nobody else)". Instead, (28b) simply signals that the occurrence of the object referent in the predication was not presupposed.

(28) Kazym Khanty (Juil'sk; Moldanov 2001: 177)

Context: At the end of an episode the protagonist and his magic helping horse arrive at their home country. The horse speaks to him: 
a. Mănot šŏgs-e, $\quad p a$ tŭt $\lambda e v$-um $x \breve{\lambda} \lambda-\partial \eta \quad a \eta k \partial \lambda-a$

me.ACC 1 kick-IMP.SBJ2SG.OBJSG again fire eat-PTCP spruce-ADJ stump-LAT

at $j i-\lambda$-um

OPT become-PRS-1sG

'[Kick $]_{\mathrm{FoC}}$ me, and I will turn into a burned spruce stump again'

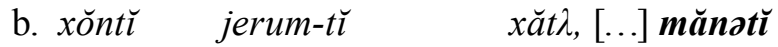

sometime be.necessary-PTCP day me.ACC 2 taגta kănš-e.

from.here search-IMP.SBJ2SG.OBJSG

'one day, when necessary, [...] [look for me here $]_{\mathrm{Foc}}$ !'

A successful interpretation for the variation in (29) can be achieved by establishing a verum focus reading for (29b). First, in (29a), the complex form expresses inclusion of the object expression into the focus. In (29b) then, the simple, non-focal form, enables a reading with verum focus in a repetition context. (Again, we mark this focus type by a narrow focus on the auxiliary in the English translation.)

(29) Kazym Khanty (Kazym; Moldanov 2001: 180)

Context: The elder brothers of the protagonist set off to find themselves brides for marriage. He desperately wants to join them, but they refuse to take him along.

a. Aj aple- $\lambda \quad j a j-\eta a-\lambda$

young younger.brother-3sG elder.brother-DU-3sG

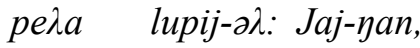

towards say-PRS brother-DU

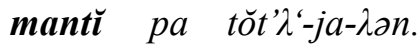
me-ACC ${ }_{2}$ also bring-IMP-2DU/PL

'The younger brother says to his brothers: Brothers, [take me along] $]_{\mathrm{FOC}}$ '' ('Mladšij brat brat'jam govorit: Brat'ja, menja tože voz'mite s soboj!')

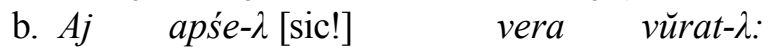

young younger.brother-3SG strongly beg-PRS

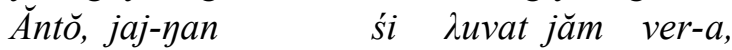

no elder.brother-DU DEM big good do-IMP2SG 


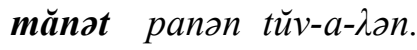

me.ACC ${ }_{1}$ with take-IMP-2DU

'The younger brother entreats: No, brothers, do such a good thing and $[\mathrm{do}]_{\mathrm{FOC}}$ take me along!'

('Mladšij brat sil'no stal prosit'sja: Net, brat'ja, sdelajte xorošoe delo, voz'mite menja s soboj.')

Finally (30), which concludes the present discussion, contrasts the two focal forms in $(30 a, b)$ with the non-focal form in (30c). The difference, in our opinion, is that in (30c) the object referent is part of the background question ("what are you supposed to do to me?"), whereas in the preceding $(30 \mathrm{a}, \mathrm{b})$ the background question does not include the object referent ("what are you supposed to do?").

(30) Kazym Khanty (Juil'sk; Moldanov 2001: 164-165)

Context: The main protagonist sets out courting. On his way he meets three helpers who ask for being taken along. The first one is a magic haystack (a.), the second one a man (b.), and the third one a giant (c.):

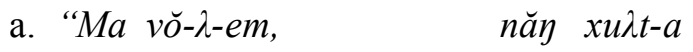

I know-PRS-SBJ1SG.OBJSG you where-LAT

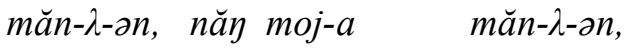

go-PRS-2SG you courting-LAT go-PRS-2SG

mantĭ tŭv-e."

me.ACC2 take-IMP.SBJ2SG.OBJSG

"'I know where you are going, you go courting, [take me along $]_{\mathrm{FO}}$ !" (Ja znaju, ty kuda edeš', ty svatat'sja edeš', menja voz'mi s soboj.)'

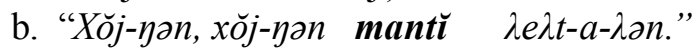
man-DU man-DU me.ACC2 transport-IMP-2DU/PL

"'Men, men, [take me along $]_{\mathrm{FO}}$ !"

(Mužiki, mužiki! Voz'mite menja s soboj!)'

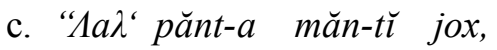

war way-LAT go-PTCP people

moj pănt-a măn-ť jox

courting way-LAT go-PTCP people

mănot $\lambda e \lambda t-a-\lambda \partial n . "$

me.ACCl transport-IMP-2DU/PL 
"'People going to war, people going to court, [take $[\mathrm{me}]_{\text {TOP }}$ along $]_{\mathrm{Foc}}$ "' (Na svatovskoj put' edujuščie, na voennyj put' edujuščie, voz'mite menja s soboj.)'

4.3. If our interpretations thus far are correct, we face in Kazym a situation contrary to that in Vym' and Luza: while the Komi dialects have developed a new complex case form for non-focal pronominal object expressions, Kazym developed a complex form for focal object expressions. What both languages share is that they differentiate between focal and non-focal pronominal direct objects. The purpose of this differentiation can be understood as focus precision.

\section{Conclusions and outlook}

The DOM pattern which appears in the data presented in this paper cannot be sufficiently explained by the categories of definiteness, animacy and affectedness. Instead, it can be demonstrated that an explanation in terms of information structure is possible, i.e., in terms of discourse topic and focus. To be more exact, it can be demonstrated that variation in marking the direct object is an instrument for defining the size of focus within a sentence. In addition to the common accusative form of a pronominal direct object, the Uralic languages, discussed above, created a second case form which explicitly indicates that the object expression is either part of the focus (Kazym) or outside of the focus (Vym', Luza). It seems, among Uralic languages, that focus sensitive DOM appears with personal pronouns in a special area, including dialects of Komi and Khanty. Is this exhaustive, or have comparable patterns up to this point been overlooked? 


\section{Acknowledgements}

This is a revised and slightly extended version of an earlier paper (Klumpp 2011).

\section{Address:}

Gerson Klumpp

Institute of Estonian and General Linguistics

University of Tartu

Jakobi 2

51004 Tartu, Estonia

E-mail:klumpp@ut.ee

\section{Abbrevations}

In the glossings appear the following abbreviations not included in Leipzig glossing rules: AFF affirmative particle, $\mathrm{CN}$ connegative stem, CTOP contrastive topic, ILL illative case, INE inessive case, LAT lative case, OPT optative particle, PRE presupposition, PTV partitive case.

\section{References}

Aissen, Judith (2003) "Differential Object Marking: Iconicity vs. Economy." Natural Language and Linguistic Theory 21, 435-483.

Alvre, Paul (1987) "O padežax ob"ekta (prjamogo dopolnenija) v finnougorskix jazykax.” In Mixail G. Atamanov, ed., XVII. vsesojuznaja finno-ugorskaja konferencija 1: Jazykoznanie (tezisy dokladov), 3-14. Ustinov.

Baker, Robin (1985) The development of the Komi case system: a dialectological investigation. (Mémoires de la Société Finno-Ougrienne, 189.) Helsinki: Suomalais-Ugrilainen Seura.

Batalova, Raisa M. (1975) Komi-permjackaja dialektologija. Moskva: Nauka.

Bossong, Georg (1998) "Le marquage différentiel de l'objet dans les langues d'Europe." In Jack Feuillet, ed., Actance et valence dans les langues de l'Europe, 193-258. Berlin and New York: Mouton de Gruyter.

Comrie, Bernard (1975) "Subjects and direct objects in Uralic languages: a functional explanation of case-marking systems." Études Finno-Ougriennes $12,5-17$. 
Denison, Norman (1957) The partitive in Finnish. (Suomalaisen Tiedeakateemian Toimituksia, Sarja B, 108.) Helsinki: Suomalais-Ugrilainen Seura.

Frolova, Tat'jana I. (1950) Imennye kategorii verxne-vymskix govorov severnogo dialekta komi jazyka. Unpublished candidate's dissertation. Syktyvkar.

Frolova, Tat'jana I. (1948/1949) Materialy dialektologičeskoj ekspedicii v železnodorožnyj rajon. Čast' III: teksty. Syktyvkar: Arxiv komi naučnogo centra.

Huumo, Tuomas (2010) "Nominal aspect, quantity, and time: the case of the Finnish object.” Journal of Linguistics 46, 83-125.

Joki, Aulis J. (1944) Kai Donners Kamassisches Wörterbuch nebst Sprachproben und Hauptzügen der Grammatik. (Lexika Societatis FennoUgricae, 8.) Helsinki: Suomalais-Ugrilainen Seura.

Kiparsky, Paul (1998) "Partitive case and aspect." In Miriam Butt and Wilhelm Geuder, eds., The projection of arguments, 265-307. Stanford: Stanford University Press.

Klumpp, Gerson (2011) "Differential object marking and information structure with pronominal objects in Komi and Khanty Dialects". In Ain Haas and Peter B. Brown, eds., The Uralic world and Eurasia. Proceedings of the XIVth, XVth, and XVIth Conferences of the FinnoUgric Studies Association of Canada, 187-208. Providence: Rhode Island College.

Klumpp, Gerson (2009) "Variation in Komi object marking". In Andreas Dufter, Jürg Fleischer, and Guido Seiler, eds., Describing and modeling variation in grammar., 325-359. (Trends in Linguistics, Studies and Monographs, 204.) Berlin and New York: Mouton de Gruyter.

Kont, Karl (1963) Käändsõnaline objekt läänemeresoome keeltes. (Eesti NSV Teaduste Akadeemia Keele ja Kirjanduse Instituudi Uurimused, 9.) Tallinn: Teaduste Akadeemia Kirjastus.

Koškareva, Natalja (2001a) "The case systems of nouns and pronouns in Khanty." In Winfried Boeder and Gerd Hentschel, eds., Variierende Markierung von Nominalgruppen in Sprachen unterschiedlichen Typs., 235-254. (Studia Slavica Oldenburgensia, 4.) Oldenburg: BISVerlag.

Koškareva, Natalja B. (2001b) "Mestoimenija v xantyjskom jazyke." In Pirkko Suihkonen, Bernard Comrie, and Sergej A. Maksimov, eds. Meždunarodnyj simposium po dejktičeskim sistemam i kvantifikacii v jazykax Evropy i severnoj i central 'noj Azii, 111-113. Iževsk and Leipzig: Udmurt State University and Max Planck Institute for Evolutionary Anthropology.

Koškareva, Natalja B. (2002) "Kommunikativnaja paradigma xantyjskogo predloženija (na materiale kazymskogo dialekta)." In Natalja B. Koškareva and I. V. Oktiabr'skaja, eds., Jazyki korennyx narodov Sibiri 12, 29-44. Novosibirsk: Rossijskaja akdemija nauk. 
Koškareva, Natalja B. and Valentina N. Solovar (2004) Xănty jasăyn

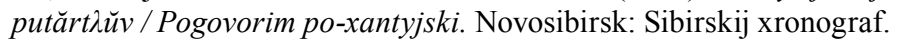

Krámský, Jiř́i (1972) The article and the concept of definiteness in language. The Hague and Paris: Mouton.

Krifka, Manfred (2007) "Basic notions of information structure". In Caroline Féry, Gisbert Fanselow, and Manfred Krifka, eds. The notions of information structure, 13-55. (Interdisziplinäre Studien zur Informationsstruktur, 6.) Potsdam: Universitätsverlag.

Kuznecov, Nikolaj, ed. (2005) Komi rahvaluulet. Kogunud P. Ariste I. Tartu: Eesti Kirjandusmuuseumi Folkloristika osakond.

Lambrecht, Knud (1994) Information structure and sentence form: topic, focus, and the mental representations of discourse referents. (Cambridge Studies in Linguistics, 71.) Cambridge: Cambridge University Press.

Larsson, Lars-Gunnar (1983) Studien zum Partitivgebrauch in den ostseefinnischen Sprachen. Uppsala: Acta Universitatis Upsalensis.

Lazard, Gilbert (2001) "Le marquage différentiel de l'objet". In M. Haspelmath, E. König, W. Oesterreicher, and W. Raible, eds. Language universals and language typology: an international handbook, 873-885. (HSK, 20.2.) Berlin and New York: Mouton de Gruyter.

Loskutova, N. I. (1972) Materialy dialektologičeskoj èkspedicii 1971 goda s. Ob”jačevo, Priluzskij r-n Komi ASSR. (Vols. 2-3). Syktyvkar: Arxiv komi naučnogo centra.

Ljašev, Vladimir A. (1977) "Nekotorye distinktivnye priznaki severnogo nul'-èlovogo areala komi jazyka". Sovetskoe Finnougrovedenie 13, 119-123.

Ljašev, Vladimir A. (1975) Fonetiko-morfologičeskie osobennosti vymskogo dialekta komi jazyka. Unpublished candidate's dissertation. Syktyvkar.

Lytkin, Vasilij I., ed. (1931) Sbornik Komissii po sobiraniju slovarja i izučeniju dialektov komi jazyka 2. Moskva.

Moldanov, Timofej (2001) Zemlja košačego lokotka / Kań kunš òăy 2. Tomsk: Izdatel'stvo Tomskogo universiteta.

Molnár, Valéria (1991) Das Topik im Deutschen und im Ungarischen. (Lunder Germanistische Forschungen, 58.) Stockholm: Almqvist and Wiksell.

Næss, Åshild (2004) "What markedness marks: the markedness problem with direct objects". Lingua 114, 1186-1212.

Nëmysova, E. A., S. P. Kononova, and E. N. Vožakova (1996) Russko-xantyjskij razgovornik. Moskva: Ikar.

Nikolaeva, Irina (2001) "Secondary Topic as a Relation in Information Structure." Linguistics 39, 1-49.

Nikolaeva, Irina (1999) "Object agreement, grammatical relations, and information structure". Studies in Language 23, 331-376.

Nikolaeva, Irina, Kovgan, Elena, and Natalia Koškareva (1993) "Communicative roles in Ostyak syntax". Finnisch-Ugrische Forschungen 51, 125-167. 
OA III = Sauer, Gert, ed. (1989) Ostjakologische Arbeiten 3. Budapest: Akadémiai Kiadó.

Pusztay, János (1975) "A determinálás kifejezése az uráli nyelvekben". Magyar Nyelvör 99, 356-364.

Rédei, Károly (1978a) Zyrian Folklore Texts. Budapest: Akadémiai Kiadó.

Rédei, Károly (1968) Nord-ostjakische Texte (Kazym-Dialekt) mit Skizze der Grammatik. (Abhandlungen der Akad. der Wiss. zu Göttingen. Phil.hist. Klasse. 3rd Series, 71.) Göttingen: Vandenhoeck \& Ruprecht.

Schwarzschild, Roger (1999) "Givenness, avoidf and other constraints on the placement of accent”. Natural Language Semantics 7, 141-177.

Serebrennikov, Boris A. (1963) Istoričeskaja morfologija permskix jazykov. Moskva: Izdat. Akademii Nauk SSSR.

Tereščenko, Natal'ja M. (1979) Nganasanskij jazyk. Leningrad: Nauka.

Tveite, Tor (2004) The case of the object in Livonian: a corpus based study. (Castrenianumin toimitteita, 62.) Helsinki: Suomalais-Ugrilainen Seura.

Vászolyi-Vasse, Eric (2001) Syrjaenica: narratives, folklore and folk poetry from eight dialects of Komi. Vol. 2: Kolva and Usa. (Specimina Sibirica, 17.) Szombathely.

Wagner-Nagy, Beáta B., ed. (2002) Chrestomathia Nganasanica. (SUA Supplementum, 10.) Szeged: Szegedi Tudományos Egyetem.

Wickman, Bo (1955) The form of the object in the Uralic languages. (Uppsala Universitets Årsskrift, 6.) Uppsala: Almqvist \& Wiksell.

Žilina Tat'jana I. (1998) Vymskij dialekt komi jazyka. Syktyvkar: Prolog.

Žilina Tat'jana I. (1985) Luzsko-letskij dialekt komi jazyka. Moskva: Nauka.

\begin{abstract}
Kokkuvõte. Gerson Klumpp: Eristav objekti markeerimine ja infostruktuur: kahe erineva pronominaalse akusatiivi funktsioonist komi ja handi murretes. Käesolev kaastöö käsitleb marginaalset kuid huvitavat variatsiooni nähtust grammatikas, nimelt kahe erineva akusatiivimarkeri kasutamist pronominaalobjektide puhul (i) komi keele ülem-võmi ja luza murretes ning (ii) kazõmi-handi murretes, s.t kahes uurali keelte harus (permi ja ugri). Kontekstuaalsetele vaatlustele põhinedes on jõutud nähtuse selgituseni, mis lähtub infostruktuurist. Mõlema keele murretes signaliseerivad täiendavad pronominaalobjekti akusatiivi vormid nende fokaalsust või mittefokaalsust. Uurimus annab panuse eristava objekti markeerimise teooriasse sellega, et võtab arvesse fokaalsuse parameetri.
\end{abstract}

Märksõnad: eristav objekti markeerimine, infostruktuur, dialektoloogia, isikulised ja osutavad asesõnad, permi keeled, ugri keeled 